\title{
The influence of foreigners' buzzing on TripAdvisor ranking of restaurants in Venice: implications for the sustainability of over-touristed heritage cities
}

\section{Andrea Ganzaroli , Ivan De Noni \& Michelle Bonera}

To cite this article: Andrea Ganzaroli , Ivan De Noni \& Michelle Bonera (2020): The influence of foreigners' buzzing on TripAdvisor ranking of restaurants in Venice: implications for the sustainability of over-touristed heritage cities, Current Issues in Tourism, DOI: 10.1080/13683500.2020.1806791

To link to this article: https://doi.org/10.1080/13683500.2020.1806791

\section{Published online: 16 Aug 2020.}

\section{Submit your article to this journal $\sqsubset$}

凹ll Article views: 25

a

View related articles

View Crossmark data $₫$ 


\title{
The influence of foreigners' buzzing on TripAdvisor ranking of restaurants in Venice: implications for the sustainability of over-touristed heritage cities
}

\author{
Andrea Ganzaroli ${ }^{a}$, Ivan De Noni ${ }^{b}{ }^{b}$ and Michelle Bonera ${ }^{c}$ \\ aDepartment of Environmental Science and Politics, University of Milano, Milano, Italy; ${ }^{\mathrm{b}}$ Department of Economics \\ and Management, University of Padua, Padova, Italy; 'Department of Economics and Management, University of \\ Brescia, Brescia, Italy
}

\begin{abstract}
Local and global coexist in any tourist destination, and the challenge of tourism sustainability is what remains in the balance between these two dimensions. Social and consumer-generated media are changing how local and global are coming together in the local system. These media's effects are even more important in overtouristed places, where a significant imbalance between local and tourist development already exists. In this paper, the effects from foreigners' reviews in crowd-based ranking systems in overtouristed cities are investigated. Based on a case study of TripAdvisor's restaurant rankings in Venice, our findings suggest that foreigners' reviews systematically rate tourist experiences' quality higher than non-foreigners' reviews, and that their attitude significantly affects the ranking of these experiences. This discloses these systems' limited reliability in overtouristed cities when it comes to rank quality, as well as the potential risks deriving from their large and uncontrolled adoption. The study concludes that a governance system is needed that is more respectful and inclusive of these places' specific requirements.
\end{abstract}

\section{ARTICLE HISTORY}

Received 28 May 2019

Accepted 30 July 2020

\section{KEYWORDS}

Overtourism; heritage cities; restaurant quality; tourist reviews; TripAdvisor; Venice

\section{Introduction}

All tourist destinations have two identities. On one hand, tourist destinations are global sites, attracting visitors from all over the world, mostly foreigners who share very little social and cultural background with the destination. On the other hand, tourist destinations also have local communities, telling their own stories of those who live in and identify with these places. It is in this interspace between local and global where we assert that a nexus exists (Bourdeau et al., 2016; Coe et al., 2008; Sanz-Ibáñez \& Clavé, 2016), in which tourist destinations' capacity to survive change, grow and develop in a sustainable manner is shaped and evolves (Butowski, 2019; Russo, 2002). Social media and consumer-generated media (CGM) are changing the structure of this local-global nexus radically. Tourist destinations are an experience good, and social media globally extend CGM's reach and influence. Therefore, CGM hold the potential to change the tourist destinations and attractions' reputation, with potentially significant implications for the spatial distribution of tourism both globally, across destinations, and locally, within each destination (Hennig-Thurau et al., 2004; Law et al., 2010; Liang et al., 2013; Litvin et al., 2008; Oetting, 2010).

This paper aims to extend the understanding of CGM's role in influencing the mode in which tourist destinations' reputations are established and leveraged. More specifically, we examine foreign tourists' travel reviews in determining tourist experiences' reputations in overtouristed 
cities. Our goal is to understand whether foreign and non-foreign reviewers systematically differ in their ratings of tourist experiences in overtouristed cities and whether this holds implications concerning these experiences' reputations. The intuition behind this paper is that foreign reviewers lack the social and cultural background required to assess local tourism experiences' authenticity (Russo, 2002). If this bias is confirmed, it implies that the efficiency of crowdsourcing rating systems, which are based on the aggregation of ratings from a large crowd of peer tourists, is compromised in overtouristed cities. Thus, unlike what is claimed and largely believed, these systems do not allow for the revelation of tourist destinations' authentic qualities. This result is of significance because it shows that crowdsourced rating systems may be not, at this stage, reliable soft solutions to the vicious cycle of tourism development (Ganzaroli et al., 2017; Russo, 2002).

We conducted our study in Venice based on data collected from TripAdvisor on restaurant rankings and ratings. Venice is a tourism vanguard as a well-researched site concerning the negative effects from overtourism (Seraphin et al., 2018) and the vicious cycle of tourism development (Russo, 2002; Van der Borg, 1992). Furthermore, existing studies have examined social media's effects on the vicious cycle of tourism development (Ganzaroli et al., 2017). In 2017, Venice hosted between 25 and 30 million tourists, of which $85 \%$ were foreigners and only 5 million stayed in the city overnight. Therefore, most would benefit from the availability of efficient crowdsourced rating systems as substitutes for their lack of time and background to process social and cultural cues that signal authenticity during a tourist/cultural experience (Caserta \& Russo, 2002; Ganzaroli et al., 2017; Russo, 2002). TripAdvisor is one of the most important travel destination and accommodation websites $^{1}$ (O'connor, 2010; Yoo et al., 2016) and is a well-researched site for tourism-related issues (Banerjee \& Chua, 2016; Fitchett \& Hoogendoorn, 2019; Fogel \& Murphy, 2018; Ganzaroli et al., 2017; Garay Tamajón \& Cànoves Valiente, 2017; Hall \& Ram, 2019; Litvin \& Dowling, 2018; Taecharungroj, 2019). Finally, restaurants more and more are viewed as integral parts of tourist offerings, rather than mere complementary services (Getz et al., 2014; Hall \& Gössling, 2016; Sidali et al., 2015; Suntikul, 2019; Williams et al., 2019). UNESCO's listing of the Gastronomic Meal of the French as Intangible Cultural Heritage of Humanity in 2010, for the first time, defined cuisine's role in cultural heritage.

Our findings confirm that foreign and non-foreign reviewers systematically rate the quality of the experience that restaurants offer in Venice differently. More specifically, we show that foreign reviewers systematically rate restaurants higher than non-foreign reviewers, and that this behaviour leads to systematic bias in restaurant rankings. Our deductive reflection on the possible consequences of this systematic bias suggests that using crowdsourced rating systems in overtouristed cities may strengthen, rather than weaken, the vicious cycle of tourist development. We conclude by arguing for the need to redesign the governance of these systems in such a way as to be more inclusive of these places' specificity and local developmental strategies.

This paper is structured in three parts: In the first part (Section 2.1), we investigate the reasons underlying the development of overtourism and touristification. We then focus on social and consumer-generated media and derive potential effects from these media on overtourism. In Section 2.3, this analysis is summed up to derive some initial hypotheses about the effects from foreigners' reviews on the ranking of tourist experiences in overtouristed cities. The second part (Section 3) focuses on methodology, in which we define data collection, variables, and the model that we implement to assess the effect of foreigners' reviews on the ranking of tourist experiences. The model's results are analysed in Section 3.3, and the study's findings are discussed in the concluding section (Section 4).

\section{Literature review}

The local-global nexus is key in shaping the endogenous evolution of tourism destinations and regions (Sanz-lbáñez \& Clavé, 2016). This is especially true for destinations already affected by overtourism. Leveraging this nexus, destination managers may exploit the capacity to target global niches of value to induce bottom-up virtuous strategic behaviour on the local level (Sanz-lbáñez \& Clavé, 
2016). Social media are changing the way local and global interact radically, with significant implications for the spatial organization of tourist flows both between and within destinations (Buhalis, 2000; Kracht \& Wang, 2010). Large players - such as TripAdvisor, Expedia and Airbnb - offer global digital platforms to bring local suppliers to globally distributed prospects. This subsection's objective is to set the stage to understand social media's effects on the development of tourism in overtouristed cities. Does global adoption of these media strengthen or weaken overtourism's negative effects?

\subsection{Overtourism and touristification}

Online travel magazine Skift coined and trademarked the term overtourism in 2016 (Ali, 2016), but research on tourism's negative effects dates back to the early 1960s (Capocchi et al., 2019; Koens et al., 2018). Those studies pointed out several factors, among others, that help transform tourism into a negative driver of local development (Capocchi et al., 2019; Dodds \& Butler, 2019; Russo \& Scarnato, 2018; Seraphin et al., 2018): the number of visitors and their distribution over time and space; the consequences from this excessive number of visitors on local residents' perceived quality of life and/or on the quality of the tourist experience; and the negative feedback triggered by overcoming destination-carrying capacity, which is defined along different thresholds (physical, ecological, psychological, social and economic).

Touristification is one of the main negative effects from overtourism and is defined as the manifold transformations of urban environments engendered by tourism growth (Freytag \& Bauder, 2018; Gravari-Barbas \& Guinand, 2017). It may take different forms in different places at different levels (Freytag \& Bauder, 2018; Gravari-Barbas \& Guinand, 2017). For instance, on a physical level, touristification is reflected in visible changes in the built environment or its functional use, such as the proliferation of souvenir shops and localized tourist services. On another level, touristification might be hardly visible, such as in the ongoing transformation of regular housing in Airbnb apartments. Finally, on the third level, touristification can be viewed from a human-agency-based perspective, with an emphasis on tourist practice and actions.

Over the past few decades, the two phenomena - overtourism and touristification - have attracted many policymakers' interest, even at national and international levels. However, overtourism still lacks a specific theoretical background. No comprehensive theory exists to identify and explain overtourism's drivers, and above all, why they are so difficult to pin down and isolate. According to our view, an essential contribution comes from the theory of the vicious cycle of tourism development (Russo, 2002). This theory is grounded on an evolutionary view of tourism development, describing it as cumulative and path-dependent, possibly ending up in a lock-in situation. In this respect, overtourism can be viewed as a lock-in situation resulting from growth-oriented developmental strategies with very high switching costs already embedded.

A cornerstone in the theory of the vicious cycle of tourism development is the rise of a great imbalance between the number of tourists, i.e. excursionists, who stay overnight in the main destination, and false excursionists, who stay overnight at a peripheral site (Van der Borg et al., 1996), as a strategy to cope with central facilities' rising prices and limited capacity. This imbalance's rise and size are important because they define the extent to which local suppliers may exploit, opportunistically, tourists' information asymmetry on the quality and authenticity of the complementary experiences offered (Caserta \& Russo, 2002). Excursionists and false excursionists have less time to search for and retrieve information on the quality of cultural and complementary products, and their chance to return soon is close to zero. Thus, as the share of excursionists and false excursionists rises over time, the opportunity to exploit information asymmetry successfully in the local market grows as well. Thus, local suppliers will find it profitable to sell poor-quality products and services at comparatively high prices, rather than try to specialize in serving specific and narrow market segments. From this perspective, digital and social media may offer the opportunity to reduce information asymmetry in the local market and encourage local suppliers to invest in quality and differentiation. However, 
Russo (2002) not only refers to the distribution of information between transacting parties, but also explicitly states that a significant part of this asymmetry is due to this information's tacit nature, which is accessible only to those who share the cultural and social background. Therefore, this asymmetry not only depends on time, but also on cultural and social background, and is correlated, as we shall argue later, with the share of foreign tourists.

\subsection{Tourism and social media}

Social media and consumer-generated media (CGM) platforms have extended the efficiency and efficacy of WOM greatly (Barreto, 2014; Boon et al., 2013; Bronner \& De Hoog, 2011; Chen et al., 2011; Filieri et al., 2015). They have expanded the breadth and depth with which information, opinions and comments are shared. Through social media, tourists can access a wider range of opinions, which are continuously and frequently updated (Bødker \& Browning, 2012; Gursoy, 2019; Litvin et al., 2008). In so doing, CGM platforms, such as TripAdvisor, can improve and expedite tourists' capacity and efficiency to access, elaborate, distribute and share information by reducing information-asymmetry issues, and in this way, moderate the vicious cycle of tourism.

However, despite social media's potential, their efficiency and efficacy depend on CGM platforms and users' capacity to assess shared information's quality and trustworthiness. This capacity relies on several factors and is why CGM might fail to discriminate quality in local destinations (Ganzaroli et al., 2017). The first factor is the kind of people and motivations that these platforms select (Munar \& Jacobsen, 2014; Yoo \& Gretzel, 2008). The second concerns the credibility perception of tips and advice on social media by users because unlike traditional WOM, in social media and aggregation systems, the source of advice is not always well known and sometimes is not even accessible (Leung et al., 2013). The final factor is the crowd's efficiency as a whole in discriminating quality. Crowds are effective mechanisms for decision making when the issue is simple, with most people in the crowd sufficiently competent to make the right choices and decisions independently from others (Sunstein, 2006).

Furthermore, the extent to which social media and user-generated media can moderate the vicious cycle of tourism and touristification in overtouristed cities effectively is not yet clear. From this perspective, only a few recent studies have attempted to examine the issue, most of which focus on Airbnb (Guttentag, 2015). For instance, Gutiérrez et al. (2017) show that Airbnb apartments spatially cluster in the proximity of principal tourist attractions, with the effect of contributing to spatial concentration of tourism. Others examine Airbnb's effects on gentrification of heritage cities (Wachsmuth \& Weisler, 2018). However, Ganzaroli et al. (2017) focus on TripAdvisor and try to assess this platform's effects on tourists' decision making about restaurants and catering services. Their findings show that quality is the major factor in determining restaurants' rankings, but TripAdvisor's efficiency in overtouristed cities is constrained by the herding effect and tourist flows' established logistics. Thus, scholars who voice their concerns about social media and review systems' potential impact on overtourism already exist (Oklevik et al., 2019).

\subsection{Modelling the influence of foreigners' reviews on TripAdvisor in Venice}

Ganzaroli et al. (2017) develop a model to assess the effects from TripAdvisor's rankings in Venice to understand the extent to which TripAdvisor may be viewed as a soft solution to the vicious cycle of tourism development. Their analysis highlights how the average quality score comprises the main factors that affect TripAdvisor's restaurant rankings in Venice. However, they also highlight how the quality score is not distributed normally, but is left-tailed. Therefore, the average restaurant rating is unexpectedly high and biased by bandwagon effects and herding behaviour (Kane et al., 2014; Kietzmann et al., 2012). This result contradicts both the hypothesis of the vicious cycle of tourism development, which predicts that products and services' quality should decline over time, 
as well as the average perception among Venetian citizens, who complain about their city's restaurant quality (Ganzaroli et al., 2017; Russo, 2002).

This supports our suspicion that such a situation might be due to an inefficiency in the crowd as whole in discriminating quality. Most people in the crowd typically are expected to be more likely to make the right decision (Sunstein, 2006). However, the theory on crowd efficiency requires some degree of competence to be successful. What happens if most people generating tips and advice lack the required competencies? Clearly, we cannot say that foreigners are less able than nonforeigners to rate restaurant and catering services' quality, but they have fewer opportunities to experience the variety and quality of local offerings. In fact, as suggested by Russo (2002), the true meaning of local quality is embedded in subtle differences that are hardly visible to tourists, but self-evident to locals.

Even if non-foreigners also may suffer from cognitive limitations and bias in their capacity to evaluate local cuisine's quality and authenticity, the effects from these limitations will be lower for nonforeign reviewers than for foreign ones. First, non-foreign tourists are more aware than foreign ones about tacit cues that fellow-countrymen apply to convey a tone of typicity to their tourist offerings. For example, for most Italians, spaghetti alla Bolognese on a menu is synonymous with tourist restaurants, but most foreigners view spaghetti alla Bolognese as part of traditional Italian cuisine. Second, locals have a higher probability of having been exposed in the past to more variety and quality in local cuisine. For instance, it is more likely to find an authentic Venetian restaurant or to get access to Venetian recipes in any Italian city, rather than in any foreign city. Third, nonforeigners are more likely to know some locals whom they can ask for advice about good restaurants. Fourth, locals have more capacity to relate with people in local networks. For instance, they are less exposed to the risks of misunderstanding due to foreign language barriers. Thus, we expect nonforeign reviewers to rate local tourist experiences differently than foreign ones. Furthermore, we also expect them to be less exposed to the bandwagon effect and herding behaviour. Thus, the following hypotheses are proposed:

\footnotetext{
$\mathrm{H}_{1}$ : A significant gap exists between non-foreign and foreign reviewers in rating local tourist experiences' quality and authenticity. Foreign reviewers systemically rate local tourist experiences' quality higher than non-foreign reviewers.
}

$\mathrm{H}_{2}$ : Foreign reviewers' tendency to rate the quality of local tourist experiences' higher than non-foreign reviewers significantly affects the ranking of these experiences in crowd-based ranking systems.

\section{Methodology}

The conceptual framework that this study follows surrounds the idea that customer-generated content might fail to support sustainable development of overcrowded tourist destinations. Based on an observed difference between foreign and non-foreign reviews' average scores across restaurants in Venice, this paper specifically examines the extent of the gap and how it might affect TripAdvisor's capacity to rank restaurants within cities affected by large volumes of foreign visitors.

As previously highlighted, Venice and TripAdvisor were selected because the first is a wellknown overtourism-city case, and the second is the most prominent user-generated content platform for restaurant evaluations. Operationally, the TripAdvisor website extrapolates' data on Venetian restaurants through a widely used scraping procedure. Although this technique's legitimacy often has been debated, it currently is not deemed illegal if the scraped data are not password-protected with logins.

Finally, regression modelling is used to investigate common determinants in TripAdvisor's ranking algorithm (such as popularity, recency and quality) by disentangling foreign and nonforeign quality perceptions' impact as relating to the increasing rate of foreign reviews. The results concern the extent of the gap between standardized coefficients of foreign and non- 
foreign reviews' average scores; how this gap affects both restaurant ranking positions and their ranking growth, as well as how restaurants benefit more from attracting higher volumes of foreigners. The study is based on the supposition that reviews are distributed randomly across restaurants and across foreign and non-foreign customers. According to this supposition, the number of reviews is used as an indicator of restaurants' popularity, with high rates of foreign reviews indicating restaurants' capacity to attract foreign customers. Variables are described in greater detail in the following sections.

\subsection{Data collection and sample}

We used Web Scraper, an add-on scraping tool developed by webscraper.io, to collect data on TripAdvisor, the most important web platform that specializes in matching tourists with restaurants at their destinations through reviews and ratings worldwide. It is based on a system of peer-topeer reviews. Restaurants and catering services are ranked geographically based on popularity (number of reviews) and customers' perceived quality, which is assessed through a five-point Likert scale, i.e. ranging from 1 to 5 . Tourists mostly use TripAdvisor to search for restaurants and catering services at tourist destinations. Therefore, it is a significant source from which to collect data on the phenomena under investigation (Filieri et al., 2015; Ganzaroli et al., 2017). We choose web-scraping software instead of other data-gathering methods for a couple of reasons. First, it is more efficient. The data collection process, once you set up the crawler, is fully automated and allows you to cover all the restaurants ranked by TripAdvisor in a city. Second, the collected data are of higher quality than data collected using other data collection methods, as tourists are not interviewed, but spontaneously review \restaurants' quality. Even if fake reviews are posted, their numbers, in a city like Venice, with thousands of reviews each year, are never high enough to affect search results' quality significantly.

Data were collected twice over a one-year period, between 20 June 2015 and 20 June 2016. The first time the crawler was used, it retrieved data from 770 out of 1,071 restaurants listed on TripAdvisor. However, some of them were not geo-localized in Venice, as TripAdvisor was inclined to merge Venice and Venice-Mestre. Moreover, a large number of restaurants lacked reviews, thereby reducing the sample to 575 restaurants. During the second run, we collected data only on the restaurants already present in our dataset. However, due to closed restaurants or incorrect data (e.g. in some cases, the total number of reviews decreased between the first and second data-collection attempts), the final dataset comprised 511 restaurants. For each restaurant, we collected pertinent information, such as ranking, total reviews, number of Italian reviews per valuation (excellent, very good, good, bad, very bad), number of reviews per season and per customer category, the date of the first review and location. The number of Italian reviews per restaurant was collected by adjusting the crawler's language option, and the number of foreign reviews was calculated as the difference between the distributions of total and Italian reviews. Figure 1 shows a map of the main Venice restaurants as provided by TripAdvisor.

\subsection{Variables}

\subsubsection{Dependent variables}

The ranking position (RANK) of Venice restaurants was extracted from the TripAdvisor website on 20 June 2016. An inverse computation (RANK.inv $v_{t}=1-R A N K_{t} / \max \left[R_{A N K}\right]$ ) was adopted to make the model interpretation more accessible. Thus, the index varies from 0 to 1 , with 1 the highest rating and zero the lowest. RANK.inv $t_{t-1}$, which is introduced as a control variable in the model on the growth of ranking position, is operationalized in the same way, but refers to a previous data extraction (20 June 2015). Ranking position growth (RANK.GROW) is defined as the number of positions on the TripAdvisor ranking earned or lost by the same restaurant between the two extractions. It is computed as log $\left(\right.$ RANK $\left._{\mathrm{t}} / \mathrm{RANK}_{\mathrm{t}-1}\right)$. 


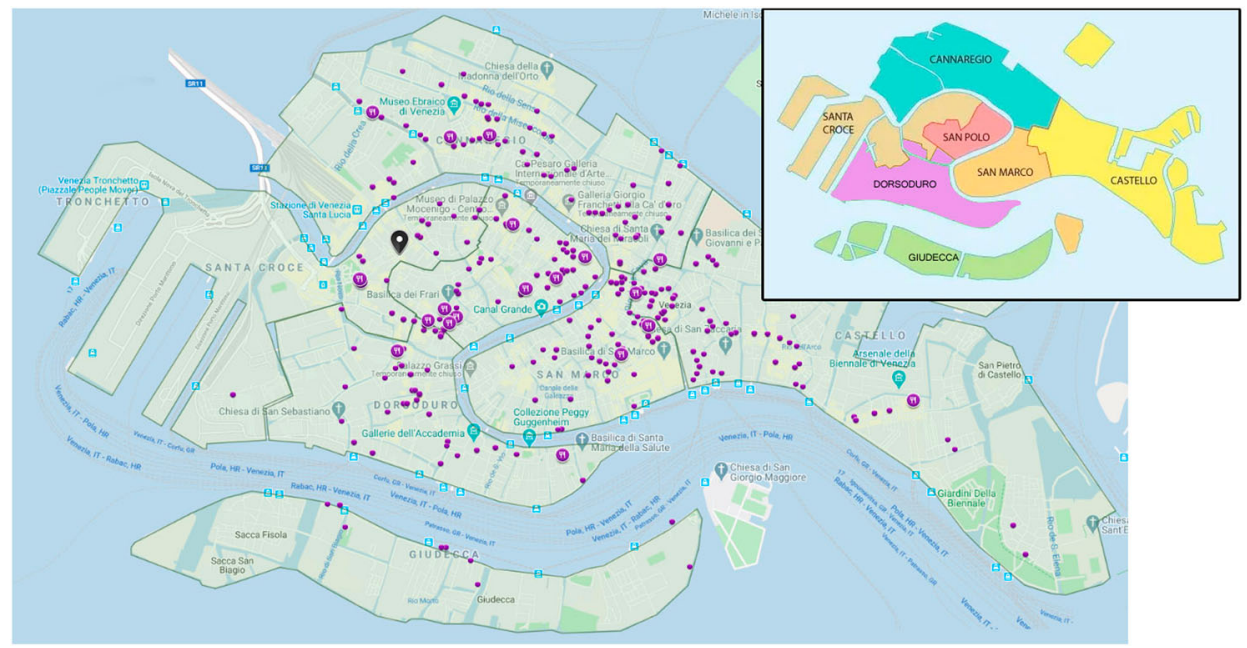

Figure 1. Map of Venetian restaurants and urban districts as provided by TripAdvisor.

\subsubsection{Exploratory variables}

The restaurant quality assessment (RQA.TOT) represents customers' perceptions of a restaurant's food, service, quality/price ratio and location. Considering that the quality assessment TripAdvisor provides is a scale varying from 1 to 5 , and a mean is not viewed as a proper measurement with its discrete, short point scale, it is computed as the percentage of very good and excellent judgements on the total number of reviews. In addition, because TripAdvisor allows for examining reviews based on reviewers' country of origin, we disentangled the measure to distinguish between RQA by nonforeign (Italian in this specific case study) customers (RQA.ITA), who are expected to provide better comparative experiences and higher food-culture proximity, and RQA from foreign customers (RQA.FOR), who are expected to have less competence in assessing food quality because they have less knowledge about Italian food culture and less comparative experience due to being present in Italy only occasionally.

The rate of foreign reviews (RATE.FOR) is a restaurant-capacity proxy to attract foreign customers. From this perspective, we intend to assess whether a restaurant's propensity to be international by attracting foreign customers produces inefficiencies in terms of food quality. We suppose that RQA.FOR's impact increases when the number of foreign customers is high, compared with the number of local customers. Data disallow obtaining an accounting of customers during any given period, so we adopted number of reviews as a proxy for number of clients. RATE.FOR is computed as the percentage of reviews from foreigners.

\subsubsection{Control variables}

Ganzaroli et al. (2017) empirically have shown that TripAdvisor's ranking relies on the quality of reviews that a restaurant receives, as well as on its popularity. For this reason, we control for the number of reviews that a restaurant has collected in the long and short terms. Specifically, longterm popularity (LONG.REV) is computed as the log-linear transformation of the total number of reviews that the restaurant received from its registration on TripAdvisor, while short-term popularity is measured as the share of reviews over the past year compared with the total number of reviews (SHORT.REV). High values depend on either a large number of recent reviews or a small number of total reviews, i.e. either the restaurant's popularity has increased during the past year, or the restaurant recently opened. Thus, considering that the number of reviews also might be tied to how long the restaurant has been open, the average number of reviews per day (RECENCY) also is introduced. 
In particular, number of days is computed by referring to the first review registered in the restaurant's TripAdvisor profile.

Finally, we attempt to achieve more robust results by including spatial positioning, seasonality and customers' categories in the models. Spatial positioning is introduced because typically in Venice, some areas are more attractive to tourists than others. A set of dummies is used to track the urban district in which each restaurant is located. Seasonality also is considered, as restaurants' customer volume fluctuates throughout the year. A set of four seasonal dummies per restaurant is defined by assigning 1 to seasons registering a higher review total than the average annual number of reviews; otherwise, zero. Similarly, we also control for the main customer categories of restaurants as clustered by TripAdvisor. A set of dummies referring to different types of customers (alone, family, business, couples, friends) is defined by assigning 1 to categories that collect more than the average annual number of reviews; otherwise, 0 .

\subsection{Analysis and results}

In Table 1, the most significant descriptive statistics are summarized. Most of the restaurants are concentrated in San Marco, Castello and Cannaregio, but the average number of reviews per restaurant is higher in San Polo, San Marco and Santa Croce because these three areas are central for typical tourism patterns. Their centrality also explains their higher capacity to attract foreign customers in absolute terms. The rate of foreign reviewers, which is more than $62 \%$ for the whole sample and varies across urban districts from $58 \%$ to $70 \%$, highlights the potential impact from foreign tourists on assessing restaurants' quality through consumer-generated media. Finally, the average quality ratings by local customers (RQA.ITA) and foreign customers (RQA.FOR) are compared at urban district and total levels. The percentage of very good and excellent reviews, on average, is $8.5 \%$ higher for foreigners compared with locals, even though it changes across urban districts by up to $12.3 \%$. The T-student test also is applied to control whether the means are significantly different from each other. The difference is significant for the total sample and for urban districts. which are statistically more representative.

Overall descriptive statistics concerning variables applied in the regression models are shown in Table 2, while the correlation matrix is reported in Table 3. RANK and RANK.GROW mainly and positively are related to all quality-assessment indicators and restaurant popularity. Since RQA.ITA and RQA.FOR are inclined to be related to each other $(r=.522)$, they are introduced one-by-one to control for collinearity risks. RQA.TOT is shown here for completeness, but is not used for analysis. Across the control variable, the only high correlation value is between LONG.REV and RECENCY ( $r$ $=.549$ ). However, the Variation Inflation Factor (VIF) suggests that no collinearity issue is relevant (the maximum VIF value per model is shown in Table 4).

Table 1. Descriptive statistics and comparison across the districts.

\begin{tabular}{|c|c|c|c|c|c|c|c|c|}
\hline Districts & $\begin{array}{l}\text { No. of } \\
\text { restaurants }\end{array}$ & $\begin{array}{l}\text { Avg. No. } \\
\text { of } \\
\text { reviews }\end{array}$ & $\begin{array}{l}\text { Avg. No. } \\
\text { of foreign } \\
\text { reviews }\end{array}$ & $\begin{array}{l}\text { Rate of } \\
\text { foreign } \\
\text { reviews }\end{array}$ & $\begin{array}{l}\text { Avg. quality } \\
\text { by local } \\
\text { customers }\end{array}$ & $\begin{array}{l}\text { Avg. quality } \\
\text { by foreign } \\
\text { customers }\end{array}$ & $\begin{array}{l}\text { Difference in } \\
\text { quality by } \\
\text { groups }\end{array}$ & $\begin{array}{l}\text { Significance } \\
\text { of } t \text { test }\end{array}$ \\
\hline CANNAREGIO & 104 & 273.37 & 156.49 & 0.583 & 0.733 & 0.802 & -0.068 & $0.003^{* *}$ \\
\hline CASTELLO & 104 & 283.57 & 189.28 & 0.619 & 0.648 & 0.755 & -0.107 & $0.000^{* * *}$ \\
\hline SAN MARCO & 100 & 346.11 & 255.23 & 0.700 & 0.627 & 0.734 & -0.107 & $0.000^{* * *}$ \\
\hline DORSODURO & 71 & 265.69 & 176.45 & 0.614 & 0.696 & 0.804 & -0.108 & $0.001^{* * *}$ \\
\hline SAN POLO & 58 & 439.29 & 269.03 & 0.603 & 0.735 & 0.800 & -0.065 & $0.055^{*}$ \\
\hline $\begin{array}{l}\text { SANTA } \\
\text { CROCE }\end{array}$ & 40 & 302.15 & 192.82 & 0.698 & 0.781 & 0.808 & -0.027 & 0.466 \\
\hline GIUDECCA & 8 & 284.50 & 182.75 & 0.674 & 0.688 & 0.810 & -0.123 & 0.241 \\
\hline $\begin{array}{l}\text { TOTAL } \\
\text { SAMPLE }\end{array}$ & 511 & 303.56 & 197.85 & 0.624 & 0.693 & 0.778 & -0.085 & $0.000^{* * *}$ \\
\hline
\end{tabular}

Note: Total sample involves 26 restaurants not assigned to any district because they are placed in the small islands around Venice. Signif. codes: ${ }^{\prime * * * \prime} 0.001^{\prime * * \prime} 0.01^{\prime * \prime} 0.05$ 
Table 2. Variables' descriptive statistics.

\begin{tabular}{lrrccccc}
\hline Variables & \multicolumn{1}{c}{ Min. } & 1st Qtr. & Median & 3rd Qtr. & Max. & Mean & SD \\
\hline RANK.inv $_{t}$ & 0.000 & 0.464 & 0.670 & 0.852 & 0.998 & 0.629 & 0.261 \\
RANK.inv $_{t-1}$ & 0.000 & 0.391 & 0.628 & 0.823 & 0.999 & 0.598 & 0.260 \\
RANK.GROW & -1.676 & -0.082 & 0.047 & 0.221 & 2.431 & 0.047 & 0.389 \\
LONG.REV & 0.000 & 4.317 & 5.242 & 5.930 & 8.765 & 5.038 & 1.318 \\
SHORT.REV & 0.000 & 0.304 & 0.380 & 0.495 & 0.938 & 0.406 & 0.172 \\
RECENCY & 0.002 & 0.062 & 0.128 & 0.245 & 5.074 & 0.192 & 0.285 \\
RQA.TOT & 0.239 & 0.659 & 0.798 & 0.867 & 1.000 & 0.757 & 0.152 \\
RQA.ITA & 0.000 & 0.564 & 0.742 & 0.859 & 1.000 & 0.693 & 0.219 \\
RQA.FOR & 0.000 & 0.697 & 0.818 & 0.897 & 1.000 & 0.778 & 0.162 \\
RATE.FOR & 0.000 & 0.504 & 0.656 & 0.773 & 0.947 & 0.624 & 0.185 \\
\hline
\end{tabular}

Table 3. Correlation matrix.

\begin{tabular}{|c|c|c|c|c|c|c|c|c|c|c|c|}
\hline & Variables & 1 & 2 & 3 & 4 & 5 & 6 & 7 & 8 & 9 & 10 \\
\hline 1. & RANK.inv $_{t}$ & 1 & & & & & & & & & \\
\hline 2. & RANK.inv $_{t-1}$ & 0.867 & 1 & & & & & & & & \\
\hline 3. & RANK.GROW & 0.244 & -0.184 & 1 & & & & & & & \\
\hline 4. & LONG.REV & 0.632 & 0.507 & 0.066 & 1 & & & & & & \\
\hline 5. & SHORT.REV & 0.155 & 0.052 & 0.191 & -0.085 & 1 & & & & & \\
\hline 6. & RECENCY & 0.409 & 0.355 & 0.039 & 0.549 & 0.049 & 1 & & & & \\
\hline 7. & RQA.TOT & 0.687 & 0.725 & 0.090 & 0.011 & 0.091 & 0.165 & 1 & & & \\
\hline 8. & RQA.ITA & 0.608 & 0.662 & 0.029 & 0.053 & 0.026 & 0.148 & 0.861 & 1 & & \\
\hline 9. & RQA.FOR & 0.608 & 0.624 & 0.090 & 0.082 & 0.211 & 0.146 & 0.752 & 0.522 & 1 & \\
\hline 10. & RATE.FOR & 0.080 & 0.027 & 0.041 & 0.169 & 0.211 & 0.115 & -0.097 & -0.211 & 0.049 & 1 \\
\hline
\end{tabular}

Table 4. OLS regression modelling results.

\begin{tabular}{|c|c|c|c|c|c|c|}
\hline \multicolumn{7}{|c|}{ OLS Model results } \\
\hline & \multicolumn{6}{|c|}{ Dependent variable } \\
\hline & \multicolumn{5}{|c|}{ Ranking position } & \multirow{2}{*}{$\begin{array}{l}\text { Ranking growth } \\
\text { (6) }\end{array}$} \\
\hline & (1) & (2) & (3) & (4) & (5) & \\
\hline Constant & $\begin{array}{c}-1.920^{* * *} \\
(0.375)\end{array}$ & $\begin{array}{c}-2.484^{* * *} \\
(0.187)\end{array}$ & $\begin{array}{c}-2.226^{* * *} \\
(0.222)\end{array}$ & $\begin{array}{c}-2.162^{* * *} \\
(0.250)\end{array}$ & $\begin{array}{c}-2.469^{* * *} \\
(0.182)\end{array}$ & $\begin{array}{c}-2.919^{* * *} \\
(0.486)\end{array}$ \\
\hline RANK.inv $_{t-1}$ & - & - & - & - & - & $\begin{array}{c}-1.175^{* * *} \\
(0.115)\end{array}$ \\
\hline LONG.REV & $\begin{array}{l}0.474^{* * *} \\
(0.076)\end{array}$ & $\begin{array}{l}0.515^{* * *} \\
(0.028)\end{array}$ & $\begin{array}{l}0.488^{* * *} \\
(0.030)\end{array}$ & $\begin{array}{l}0.471^{* * *} \\
(0.033)\end{array}$ & $\begin{array}{l}0.503^{* * *} \\
(0.024)\end{array}$ & $\begin{array}{l}0.561^{* * *} \\
(0.073)\end{array}$ \\
\hline SHORT.REV & $\begin{array}{l}0.191^{* * *} \\
(0.040)\end{array}$ & $\begin{array}{l}0.158^{* * *} \\
(0.023)\end{array}$ & $\begin{array}{l}0.191^{* * *} \\
(0.031)\end{array}$ & $\begin{array}{l}0.130^{* * *} \\
(0.027)\end{array}$ & $\begin{array}{l}0.154^{* * *} \\
(0.024)\end{array}$ & $\begin{array}{l}0.251^{* * *} \\
(0.047)\end{array}$ \\
\hline RECENCY & $\begin{array}{l}0.056 \\
(0.202)\end{array}$ & $\begin{array}{c}-0.087 \\
(0.056)\end{array}$ & $\begin{array}{c}-0.041 \\
(0.037)\end{array}$ & $\begin{array}{c}-0.050 \\
(0.029)\end{array}$ & $\begin{array}{r}-0.083^{*} \\
(0.037)\end{array}$ & $\begin{array}{c}-0.107 \\
(0.104)\end{array}$ \\
\hline RQA.TOT & - & $\begin{array}{l}0.683^{* * *} \\
(0.024)\end{array}$ & - & - & - & - \\
\hline RQA.ITA & - & - & $\begin{array}{l}0.569^{* * *} \\
(0.035)\end{array}$ & $\begin{array}{l}0.408^{* * *} \\
(0.052)\end{array}$ & $\begin{array}{l}0.317^{* * *} \\
(0.036)\end{array}$ & $\begin{array}{l}0.376^{* * *} \\
(0.091)\end{array}$ \\
\hline RQA.FOR & - & - & - & $\begin{array}{l}0.337^{* * *} \\
(0.066)\end{array}$ & $\begin{array}{l}0.450^{* * *} \\
(0.039)\end{array}$ & $\begin{array}{l}0.668^{* * * *} \\
(0.103)\end{array}$ \\
\hline RATE.FOR & - & - & - & - & $\begin{array}{l}0.040 \\
(0.022)\end{array}$ & $\begin{array}{l}0.015 \\
(0.053)\end{array}$ \\
\hline RQA.FOR*RATE.FOR & - & - & - & - & $\begin{array}{l}0.136^{* * *} \\
(0.020)\end{array}$ & $\begin{array}{l}0.217^{* * *} \\
(0.040)\end{array}$ \\
\hline District dummy & Yes & Yes & Yes & Yes & Yes & Yes \\
\hline Season dummy & Yes & Yes & Yes & Yes & Yes & Yes \\
\hline Customer category dummy & Yes & Yes & Yes & Yes & Yes & Yes \\
\hline Obs. & 511 & 511 & 511 & 511 & 511 & 509 \\
\hline max VIF & 1.394 & 1.397 & 1.394 & 1.397 & 1.444 & 2.12 \\
\hline$R^{2}$ & 0.486 & 0.895 & 0.776 & 0.847 & 0.881 & 0.411 \\
\hline Adjusted $\mathrm{R}^{2}$ & 0.465 & 0.891 & 0.767 & 0.841 & 0.875 & 0.381 \\
\hline F Statistic & $24.050^{* * *}$ & $206.287^{* * *}$ & $83.821^{* * *}$ & $127.497^{* * *}$ & $154.670^{* * *}$ & $13.858^{* * *}$ \\
\hline
\end{tabular}

Notes: ${ }^{*} p<0.05 ;{ }^{* *} p<0.01 ;{ }^{* * *} p<0.001$

Standardized coefficients are shown.

Robust Standard Errors are in parentheses. 
Finally, regression analysis is implemented to assess the determinants of TripAdvisor rankings by disentangling foreign and Italian reviewers' perceptions of restaurant quality. The results from regression models are conveyed in Table 4. Specifically, Models (1) and (2) control for restaurants' long-term and short-term popularity, recency of reviews and total quality perception throughout the reviews, as they are well-known triggers of the ranking algorithm (Ganzaroli et al., 2017). Then, in Models (3) and (4), RQA.TOT is disentangled by introducing RQA.ITA and RQA.FOR one-by-one. The full Model (5) also includes the percentage of foreign reviews (RATE.FOR) and the interaction effect with RQA.FOR. Finally, Model (6) estimates exploratory variables' impact on growth in ranking position (RANK.GROW). In this case, the ranking position in $\mathrm{t}-1$ is involved as a further control. It is important to recall that the ranking scale is inverted to make the model interpretation process easier.

Concerning the control variables, long-term popularity (LONG.REV) and short-term popularity (SHORT.REV) are positive and significant. In addition, the time frame during which the restaurant is registered on the TripAdvisor platform is insignificant if more significant time is not related to a higher number of reviews regarding competitors. As explained above, the model also controls for the urban district where the restaurant is embedded, for seasons, when the restaurant is the busiest and for customer category, to which the restaurant is more attractive.

Introducing exploratory variables one-by-one allows controlling for collinearity issues due to there not being excessively high correlation levels between some variables. Maximum VIF values are shown to be lower than 2 in all models by confirming the lack of collinearity risks. The persistence of signs and the significance of the same variables across models suggest some degree of robustness in the modelling process. Furthermore, robust OLS estimators also are provided by computing heteroscedasticity-consistent standard errors. High values of R-squared and F-test significance ultimately confirm the results' consistency.

Model results highlight that restaurant-quality assessment is a crucial determinant of TripAdvisor ranking positions (Model 2). Natives and foreigners' quality perceptions are both positive and significant (Models 3 and 4). However, the introduction of RQA.FOR in Model (4) decreases the standardized weight of the RQA.ITA estimator with respect to Model (3). Even R-squared significantly increases from Model (3) to (4) by suggesting a major explanation capacity for the model, including RQA.FOR. In the full Model (5), the rate of foreign reviews as a proxy of restaurants' capacity to attract foreign tourists is added. Previous remarks are confirmed. Also, based on the supposition that foreigners' quality perception is specifically important in the case of restaurants that are attractive to international tourists, the interaction effect between RQA.FOR and RATE.FOR is tested further. Findings suggest that the share of foreign customers is not a significant factor per se in explaining online restaurant reputation, but plays an increasingly significant role when the perceived quality of the restaurant is high. Finally, Model (6) points out that a high level of perceived restaurant quality might influence an improvement in ranking position as well. Like the previous full model, foreigners' assessments appear to make more of an impact than natives' assessments and are consistent with the interaction effect with the share of foreign customers. The merging of model results with Table 1's outputs drives some interesting considerations that are discussed in depth in the next section.

\section{Conclusion}

This study's objective was to investigate foreign reviewers' effect on restaurant rankings in an overtouristed heritage city - in this case, Venice. Our findings confirm that significant differences exist between foreign and national (Italian) reviewers in rating Venice restaurants' quality: Foreigners generate higher ratings than Italians. This tendency significantly affects both TripAdvisor's rankings and restaurants' ranking improvement, i.e. it implies that restaurants with a greater share of foreign reviews tend to be ranked higher on TripAdvisor and can improve their ranking more quickly. The effects from foreigners' reviews are present in all sestieri (neighbourhoods), except for Giudecca and Santa Croce. 
These results contribute significantly to our understanding of social and consumer-generated media's effect on the management of tourism in overtouristed cities and destinations. Although digital technologies are expected to improve tourists' access to data and information on local destinations (Munar \& Jacobsen, 2014; Nilashi et al., 2019; Peeters et al., 2019; UNWTO, 2018; Warren et al., 2018), numbers of likes and positive reviews in already-overtouristed cities or specific sites attract even more excursionists and foreign tourists (Oklevik et al., 2019). The power to influence these signals is greater for those who are less acquainted with a tourist destination, so these systems will steer a growing number of excursionists and foreigners toward tourist restaurants instead of restaurants that offer an authentic, local food experience, potentially eliciting negative effects on the overall local food chain's quality and development. Thus, social media will contribute even more to congestion, rather than quality of life, around tourism sites. Furthermore, as suggested by Ganzaroli et al. (2017), the tourist path is not independent from the representation of that city in social media, which may become tools that trigger expectations concerning self-fulfilment and realisation as reviews continuously promote already-known places' popularity and quality.

The literature review highlights how the competence of people in the crowd is important to determine the crowd's efficiency in making the right choice. Ganzaroli et al. (2017) already have shown that these conditions are not likely to hold in Venice, as the restaurant distribution rate is left-tailed, in contrast to residents' concerns over restaurants' lack of quality and the touristification of products and services in the city. Our findings add to this result, showing that systematic bias permeates a large share of foreign reviewers, who systematically rate Venice restaurants' quality higher. This confirms that the uncontrolled development of social media and crowd-based recommendation platforms is not going to be a soft solution to the vicious cycle of tourism development and overtourism's negative effects.

These results correspond with those of other papers that have begun to examine the relationship between new digital platforms and overtourism. Airbnb has attracted the most attention so far. Evidence shows that Airbnb has led to significant incremental changes in the number of tourist rental apartments, which are concentrated mainly, even more than hotels, near cities' principal tourist attractions (Gutiérrez et al., 2017). The result is the acceleration of touristification and gentrification of heritage cities and neighbourhoods, which become ever more inaccessible to citizens (Wachsmuth \& Weisler, 2018). Our paper suggests that other platforms, such as TripAdvisor, may contribute to the touristification process. The dominant effect that foreign tourists exert on TripAdvisor's restaurant rankings extends the opportunity for these restaurants to exploit information asymmetry in the local market to offer low-quality service for a comparatively high price. Furthermore, the dominant role that tourists play in restaurant rankings further encourages restaurant owners to cater to foreign tourists' tastes, rather than to focus on the typicality of the service offered.

Therefore, improving smart technologies' efficiency in providing higher-quality tourist experiences while simultaneously improving tourism development's sustainability at the destination requires redefining the way these technologies are developed (Gössling \& Hall, 2019). So far, either large global corporations, such as TripAdvisor, or small local entrepreneurs/consortia develop these technologies.

On one hand, global corporations have an incentive to simplify the context and produce a standardized algorithm that works reasonably well in all contexts, but in so doing, these global players contribute to the standardization of the tourist experience across destinations. For instance, TripAdvisor, in increasing the visibility of restaurants that are more attractive to a foreign audience, helps strengthen the process of homogenizing the food experience across tourist areas. However, in the long run, the dissatisfaction that this homologation process generates through these tools will lead to users looking for alternative tools grounded in a different set of social and cultural values. For instance, this is what happened in the case of slow food, which has attracted diffused dissatisfaction with the current global model of food production becoming a globalized movement as well. TripAdvisor's decision to launch the platform TheFork probably is an attempt to retain the segment of users who are dissatisfied with TripAdvisor. 
On the other hand, local entrepreneurs, consortia and municipalities that are attempting to produce in-house smart solutions to cope with problems generated by tourism lack the resources and scale required to be competitive with these global players. For instance, the cost to launch a local platform that provides tourists with certified information on the quality and authenticity of the food experience that Venetian restaurants offer would be enormous. First, it would be necessary to make tourists aware of this local platform's existence. Second, tourists would need to download an app on their smartphones and create an account - all this for an app that can be used only in Venice and is deleted as soon as tourists leave the city. Therefore, such local initiatives fail to trigger the network externalities required to sustain the adoption of such in-house solutions.

Therefore, we believe there is room for collaboration between global and local players. On one hand, global players need local and contextual know-how to improve their algorithms' efficiency on each local context's specificity. On the other hand, local players need the worldwide reach that global players can provide with the global network and platform. Thus, global players and local institutions should collaborate to help generate local entrepreneurial initiatives and community action to integrate the local algorithm's functionalities with the development of more sustainable and inclusive tourism. Moreover, sustainability - which also is related to tourists' satisfaction, local service improvement and investment attraction - plays a key role in fostering touristic destination competitiveness (Goffi et al., 2019).

Finally, some limitations of the present research study need to be addressed. First, focussing on a specific city, as well as on a specific web platform, might be reductive. However, it should be noted that many studies on tourism's impact in Venice have anticipated many of the issues that emerged in other tourist cities later. Thus, our results can provide scholars with an initial benchmark they can use to assess social media in other tourism contexts. Furthermore, other peculiarities make Venice a unique case. First, the city is an island separated from the rest of the city. Second, it is a fully pedestrian historical centre. However, from our perspective, these differences are ever more becoming an issue. Most European historical centres are neighbourhoods within much larger cities, and large parts of these centres have been pedestrianized. Thus, reviews might not be representative of the population. The ranking position could change when users look for restaurants via mobile phones.

\section{Note}

1. It covers more than 8 million listings for restaurants, hotels, vacation rentals and attractions. In 2018 , it attracted approximately 730 million reviews and opinions (source: https://www.statista.com/topics/3443/tripadvisor/ (Last time accessed on January the 5th at $11.26 \mathrm{am}$ ).

\section{Acknowledgements}

This research received funding from the EU's programme HORIZON 2020 under the Grant Agreement no.870753. The authors thank the receiving editor Luna Jorgie Lyn and the anonymous reviewers whose thoughtful critique helped to improve the paper. All errors remain the authors' responsibility.

\section{Disclosure statement}

No potential conflict of interest was reported by the author(s).

\section{Funding}

This work was supported by Horizon 2020 Framework Programme: [Grant Number 870753].

\section{ORCID}

Ivan De Noni (D) http://orcid.org/0000-0001-8746-6572 


\section{References}

Ali, R. (2016). Exploring the Coming Perils of Overtourism. Skift. Available online: https://skift.com/2016/08/23/exploringthe-coming-perils-of-overtourism/ (accessed on 08 August 2020).

Banerjee, S., \& Chua, A. Y. (2016). In search of patterns among travellers' hotel ratings in TripAdvisor. Tourism Management, 53, 125-131. https://doi.org/10.1016/j.tourman.2015.09.020

Barreto, A. M. (2014). The word-of-mouth phenomenon in the social media era. International Journal of Market Research, 56(5), 631-654. https://doi.org/10.2501/JMR-2014-043

Bødker, M., \& Browning, D. (2012). Beyond destinations: Exploring tourist technology design spaces through local-tourist interactions. Digital Creativity, 23(3-4), 204-224. https://doi.org/10.1080/14626268.2012.709939

Boon, E., Bonera, M., \& Bigi, A. (2013). Measuring hotel service quality from online consumer reviews: A proposed method, in Information and Communication Technologies in Tourism 2014, Springer International Publishing, 367-379.

Bourdeau, L., Gravari-Barbas, M., \& Robinson, M. (Eds.). (2016). World heritage sites and tourism: Global and local relations. Taylor \& Francis.

Bronner, F., \& De Hoog, R. (2011). Vacationers and eWOM: Who posts, and why, where, and what? Journal of Travel Research, 50(1), 15-26. https://doi.org/10.1177/0047287509355324

Buhalis, D. (2000). Marketing the competitive destination of the future. Tourism Management, 21(1), 97-116. https://doi. org/10.1016/S0261-5177(99)00095-3

Butowski, L. (2019). Tourist sustainability of destination as a measure of its development. Current Issues in Tourism, 22(9), 1043-1061. https://doi.org/10.1080/13683500.2017.1351926

Capocchi, A., Vallone, C., Amaduzzi, A., \& Pierotti, M. (2019). Is 'overtourism'a new issue in tourism development or just a new term for an already known phenomenon? Current Issues in Tourism, 1-5. https://doi.org/10.1080/13683500.2019. 1638353

Caserta, S., \& Russo, A. P. (2002). More means worse: Asymmetric information, spatial displacement and sustainable heritage tourism. Journal of Cultural Economics, 26(4), 245-260. https://doi.org/10.1023/A:1019905923457

Chen, Y., Fay, S., \& Wang, Q. (2011). The role of marketing in social media: How online consumer reviews evolve. Journal of Interactive Marketing, 25(2), 85-94. https://doi.org/10.1016/j.intmar.2011.01.003

Coe, N. M., Dicken, P., \& Hess, M. (2008). Global production networks: Realizing the potential. Journal of Economic Geography, 8(3), 271-295. https://doi.org/10.1093/jeg/lbn002

Dodds, R., \& Butler, R. (Eds.). (2019). Overtourism: Issues, realities and solutions (Vol. 1). De Gruyter Oldenbourg.

Filieri, R., Alguezaui, S., \& McLeay, F. (2015). Why do travelers trust TripAdvisor? Antecedents of trust towards consumergenerated media and its influence on recommendation adoption and word of mouth. Tourism Management, 51, 174185. https://doi.org/10.1016/j.tourman.2015.05.007

Fitchett, J. M., \& Hoogendoorn, G. (2019). Exploring the climate sensitivity of tourists to South Africa through TripAdvisor reviews. South African Geographical Journal, 101(1), 91-109. https://doi.org/10.1080/03736245.2018.1541022

Fogel, J., \& Murphy, K. (2018). Intentions to Use the TripAdvisor review website and purchase behavior after reading reviews. Human IT: Journal for Information Technology Studies as a Human Science, 14(1), 59-100.

Freytag, T., \& Bauder, M. (2018). Bottom-up touristification and urban transformations in Paris. Tourism Geographies, 20(3), 443-460. https://doi.org/10.1080/14616688.2018.1454504

Ganzaroli, A., De Noni, I., \& van Baalen, P. (2017). Vicious advice: Analyzing the impact of TripAdvisor on the quality of restaurants as part of the cultural heritage of Venice. Tourism Management, 61, 501-510. https://doi.org/10.1016/j. tourman.2017.03.019

Garay Tamajón, L., \& Cànoves Valiente, G. (2017). Barcelona seen through the eyes of TripAdvisor: Actors, typologies and components of destination image in social media platforms. Current Issues in Tourism, 20(1), 33-37. https://doi.org/10. 1080/13683500.2015.1073229

Getz, D., Robinson, R., Andersson, T., \& Vujicic, S. (2014). Foodies and food tourism. Goodfellow Publishers.

Goffi, G., Cucculelli, M., \& Masiero, L. (2019). Fostering tourism destination competitiveness in developing countries: The role of sustainability. Journal of Cleaner Production, 209, 101-115. https://doi.org/10.1016/j.jclepro.2018.10.208

Gössling, S., \& Hall, C. M. (2019). Sharing versus collaborative economy: How to align ICT developments and the SDGs in tourism? Journal of Sustainable Tourism, 27(1), 74-96. https://doi.org/10.1080/09669582.2018.1560455

Gravari-Barbas, M., \& Guinand, S. (2017). Introduction: Addressing tourism-gentrification processes in contemporary metropolises. In M. Gravari-Barbas \& S. Guinand (Eds.), Tourism and gentrification in Contemporary Metropolises (pp. 1-21). London: Routledge.

Gursoy, D. (2019). A critical review of determinants of information search behavior and utilization of online reviews in decision making process. International Journal of Hospitality Management, 76, 53-60. https://doi.org/10.1016/j.ijhm. 2018.06.003

Gutiérrez, J., García-Palomares, J. C., Romanillos, G., \& Salas-Olmedo, M. H. (2017). The eruption of Airbnb in tourist cities: Comparing spatial patterns of hotels and peer-to-peer accommodation in Barcelona. Tourism Management, 62, 278291. https://doi.org/10.1016/j.tourman.2017.05.003

Guttentag, D. (2015). Airbnb: Disruptive innovation and the rise of an informal tourism accommodation sector. Current Issues in Tourism, 18(12), 1192-1217. https://doi.org/10.1080/13683500.2013.827159 
Hall, C. M., \& Gössling, S. (2016). From food tourism and regional development to food, tourism and regional development: Themes and issues in contemporary foodscapes. In C. M. Hall \& S. Gössling (Eds.), Food tourism and regional development: Networks, products and trajectories. (pp. 19-74). London: Routledge. https://doi.org/10.4324/ 9781315691695

Hall, C. M., \& Ram, Y. (2019). Measuring the relationship between tourism and walkability? Walk score and English tourist attractions. Journal of Sustainable Tourism, 27(2), 223-240. https://doi.org/10.1080/09669582.2017.1404607

Hennig-Thurau, T., Gwinner, K. P., Walsh, G., \& Gremler, D. D. (2004). Electronic word-of-mouth via consumer-opinion platforms: What motivates consumers to articulate themselves on the internet? Journal of Interactive Marketing, 18(1), 3852. https://doi.org/10.1002/dir.10073

Kane, G. C., Alavi, M., Labianca, G., \& Borgatti, S. P. (2014). What's different about social media networks? A framework and research agenda. MIS Quarterly, 38(1), 275-304.

Kietzmann, J. H., Silvestre, B. S., McCarthy, I. P., \& Pitt, L. F. (2012). Unpacking the social media phenomenon: Towards a research agenda. Journal of Public Affairs, 12(2), 109-119. https://doi.org/10.1002/pa.1412

Koens, K., Postma, A., \& Papp, B. (2018). Is overtourism overused? Understanding the impact of tourism in a city context. Sustainability, 10(12), 4384. https://doi.org/10.3390/su10124384

Kracht, J., \& Wang, Y. (2010). Examining the tourism distribution channel: Evolution and transformation. International Journal of Contemporary Hospitality Management, 22(5), 736-757. https://doi.org/10.1108/09596111011053837

Law, R., Qi, S., \& Buhalis, D. (2010). Progress in tourism management: A review of website evaluation in tourism research. Tourism Management, 31(3), 297-313. https://doi.org/10.1016/j.tourman.2009.11.007

Leung, D., Law, R., Van Hoof, H., \& Buhalis, D. (2013). Social media in tourism and hospitality: A literature review. Journal of Travel \& Tourism Marketing, 30(1-2), 3-22. https://doi.org/10.1080/10548408.2013.750919

Liang, S. W. J., Ekinci, Y., Occhiocupo, N., \& Whyatt, G. (2013). Antecedents of travellers' electronic word-of-mouth communication. Journal of Marketing Management, 29(5-6), 584-606. https://doi.org/10.1080/0267257X.2013.771204

Litvin, S. W., \& Dowling, K. M. (2018). Tripadvisor and hotel consumer brand loyalty. Current Issues in Tourism, 21(8), 842846. https://doi.org/10.1080/13683500.2016.1265488

Litvin, S. W., Goldsmith, R. E., \& Pan, B. (2008). Electronic word-of-mouth in hospitality and tourism management. Tourism Management, 29(3), 458-468. https://doi.org/10.1016/j.tourman.2007.05.011

Munar, A. M., \& Jacobsen, J. K. S. (2014). Motivations for sharing tourism experiences through social media. Tourism Management, 43, 46-54. https://doi.org/10.1016/j.tourman.2014.01.012

Nilashi, M., Ahani, A., Esfahani, M. D., Yadegaridehkordi, E., Samad, S., Ibrahim, O., MohdSharef, N., \& Akbari, E. (2019). Preference learning for eco-friendly hotels recommendation: A multi-criteria collaborative filtering approach. Journal of Cleaner Production, 215, 767-783. https://doi.org/10.1016/j.jclepro.2019.01.012

O'connor, P. (2010). Managing a hotel's image on TripAdvisor. Journal of Hospitality Marketing \& Management, 19(7), 754772. https://doi.org/10.1080/19368623.2010.508007

Oetting, M. (2010). Ripple effect: How empowered involvement drives word of mouth. Springer Science \& Business Media.

Oklevik, O., Gössling, S., Hall, C. M., Steen Jacobsen, J. K., Grøtte, I. P., \& McCabe, S. (2019). Overtourism, optimisation, and destination performance indicators: A case study of activities in Fjord Norway. Journal of Sustainable Tourism, 27(12), 1804-1824. https://doi.org/10.1080/09669582.2018.1533020

Peeters, P., Higham, J., Cohen, S., Eijgelaar, E., \& Gössling, S. (2019). Desirable tourism transport futures. Journal of Sustainable Tourism, 27(2), 173-188. https://doi.org/10.1080/09669582.2018.1477785

Russo, A. P. (2002). The "vicious circle" of tourism development in heritage cities. Annals of Tourism Research, 29(1), 165182. https://doi.org/10.1016/S0160-7383(01)00029-9

Russo, A. P., \& Scarnato, A. (2018). "Barcelona in common": A new urban regime for the 21 st-century tourist city? Journal of Urban Affairs, 40(4), 455-474. https://doi.org/10.1080/07352166.2017.1373023

Sanz-lbáñez, C., \& Clavé, S. A. (2016). Strategic coupling evolution and destination upgrading. Annals of Tourism Research, 56, 1-15. https://doi.org/10.1016/j.annals.2015.10.010

Seraphin, H., Sheeran, P., \& Pilato, M. (2018). Over-tourism and the fall of Venice as a destination. Journal of Destination Marketing \& Management, 9, 374-376. https://doi.org/10.1016/j.jdmm.2018.01.011

Sidali, K. L., Kastenholz, E., \& Bianchi, R. (2015). Food tourism, niche markets and products in rural tourism: Combining the intimacy model and the experience economy as a rural development strategy. Journal of Sustainable Tourism, 23(8-9), 1179-1197. https://doi.org/10.1080/09669582.2013.836210

Sunstein, C. R. (2006). Infotopia: How many minds produce knowledge. Oxford University Press.

Suntikul, W. (2019). Gastrodiplomacy in tourism. Current Issues in Tourism, 22(9), 1076-1094. https://doi.org/10.1080/ 13683500.2017 .1363723

Taecharungroj, V. (2019). User-generated place brand identity: Harnessing the power of content on social media platforms. Journal of Place Management and Development, 12(1), 39-70. https://doi.org/10.1108/JPMD-11-2017-0117

United Nations World Tourism Organization (UNWTO). (2018). 'Overtourism'? Understanding and managing urban tourism growth beyond perceptions.

Van der Borg, J. (1992). Tourism and urban development: The case of Venice, Italy. Tourism Recreation Research, 17(2), 4656. https://doi.org/10.1080/02508281.1992.11014649 
Van der Borg, J., Costa, P., \& Gotti, G. (1996). Tourism in European heritage cities. Annals of Tourism Research, 23(2), 306321. https://doi.org/10.1016/0160-7383(95)00065-8

Wachsmuth, D., \& Weisler, A. (2018). Airbnb and the rent gap: Gentrification through the sharing economy. Environment and Planning A: Economy and Space, 50(6), 1147-1170. https://doi.org/10.1177/0308518X18778038

Warren, C., Becken, S., Nguyen, K., \& Stewart, R. A. (2018). Transitioning to smart sustainable tourist accommodation: Service innovation results. Journal of Cleaner Production, 201, 599-608. https://doi.org/10.1016/j.jclepro.2018.08.063

Williams, H. A., Yuan, J., \& WilliamsJr.R. L. (2019). Attributes of Memorable Gastro-tourists' experiences. Journal of Hospitality \& Tourism Research, 43(3), 327-348. https://doi.org/10.1177/1096348018804621

Yoo, K. H., \& Gretzel, U. (2008). What motivates consumers to write online travel reviews? Information Technology \& Tourism, 10(4), 283-295. https://doi.org/10.3727/109830508788403114

Yoo, K. H., Sigala, M., \& Gretzel, U. (2016). Exploring TripAdvisor. In Roman Egger, Igor Gula, \& Dominik Walcher (Eds.), Open tourism: Open Innovation, Crowdsourcing and Co-Creation Challenging the Tourism Industry (pp. 239-255). Springer. https://doi.org/10.1007/978-3-642-54089-9 